\title{
ECO-GEOGRAPHIC CRITERIA FOR MAPPING FOREST HABITATS IN SOUTHEASTERN MANITOBA
}

\author{
By D. MUELLER-DOMBOIS ${ }^{1}$
}

\begin{abstract}
$A B S T R A C T$
Eco-geographic criteria for forest habitat mapping in southeastern Manitoba are presented in form of (a) an air-photo orientation key that is intended for making preliminary type lines on standard $(1: 15,840)$ air photographs and $(b)$ a field key that can be used for checking the type lines and for independent field mapping. The ecological relations of the habitat types are summarized by tabulation (Table 1) and by a profile diagram showing the habitat types as generalized ecological series (Fig. 1).
\end{abstract}

\section{INTRODUCTION}

A forest habitat type classification has recently been described for southeastern Manitoba (Mueller-Dombois 1964), which gives basic information on environments and vegetation in an attempt to apply this in terms of silvicultural research and management. The habitats were defined by vegetation, soil and physiographic position and their functions were explained by soil water and nutrient relationships that they showed with current forest growth and distribution.

The purpose of this paper is to reduce the ecological information to a few, readily recognizable criteria for mapping and to present these in a form that can be employed by foresters and others who wish to use the classification in the field. Almost concurrently Jurdant (1964) has discussed the utility of using natural distribution patterns of forest vegetation, soil and landform for identifying forest ecosystems on air photographs, which is in complete accord with the approach presented here. However, he does not describe how the units are identified. Therefore, the task of mapping still rests with the person that did the study. This paper goes one step further by providing the forester with the means of identifying the units for himself.

The area to which the classification applies is the western part of the $\mathbf{L} 12$ (Rainy River) Forest Section (Rowe 1959), which covers roughly 3,000 square miles in the southeast corner of Manitoba.

${ }^{1}$ Assistant Professoz of Botany, University of Hawaii, Honolulu 96822, Costs of publication are shared with the C.I.P. 


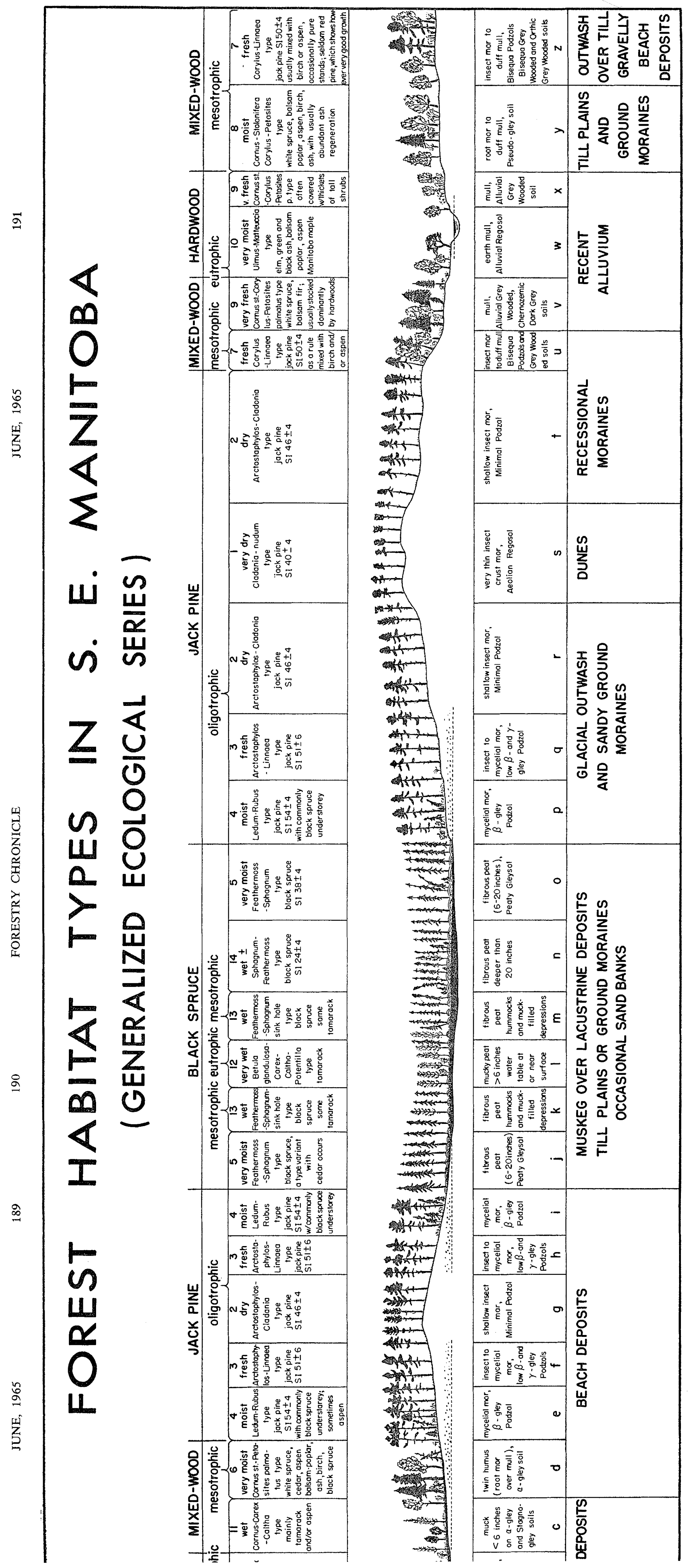




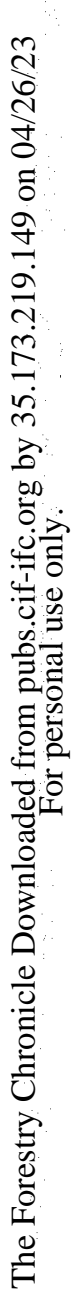


The information given is based on the above cited study, which included experimental mapping of a six-square mile area at a scale of 1:15,840. The mapping method was based on using standard air photographs (4 miles to the inch) for drawing preliminary type lines, which were then thoroughly checked, verified or corrected in the field.

On this basis an air-photo orientation key was developed that can be used as a major step toward map completion in the field. It is followed by a key for field mapping that can be used independently. In both keys existing forest conditions are used, and modifications may become necessary with intensifying management. Use of the keys requires an ability to recognize

- landform types, certain common plant species, and soil upper profile characteristics in the field. On air photographs the user should be familiar with recognizing cover types, landform types and topographic differences. A description of the air-photographic image of these landscape features was beyond the scope of this paper. They are readily learned by persons having some experience with air photographs. Aids are available for identifying tree species (SaynWittgenstein 1961, Zsilinsky 1963) and landform types (Powers 1952).

The habitat types are identified by numbers and symbols in the keys which refer to the abbreviated type descriptions shown in Table 1 and Figure 1 (a folded insert on page 189).

\section{Ecological Classification}

The ecological classification is summarized in Figure 1 and Table 1. Figure 1 shows the habitat types ( 1 to 14 ) of southeastern Manitoba as a generalized ecological series. The legend from top to bottom defines each habitat type by the ecosystem components and distribution patterns that were studied: tree cover, lesser vegetation, soil, and landform-type. Position on landform (physiographic position) is shown diagrammatically. Each habitat type represents a specific combination of nutrient and moisture regime. Essential stand information is given under lesser vegetation type; it includes mean 50-year site index (SI) with standard deviation, where reliably established.

It may be noted that habitat type 2 occurs on three positions ( $g, r, t)$ on four landform types. Each occurrence represents the same tree-physiological potential, as evidenced by the same pedogenic soil type, humus type, vegetation type, cover type and site index. On the other hand, two habitats (types 6 and 8) have similar lesser vegetation types, but different tree-physiological potentials in terms of natural regeneration trends (and probably growth rate); this is attributed to differences in the mechanisms of soil water supply. Type 6 has an alpha-gley soil, which is a true gley soil with a high permanent water table in which gleying occurs in the A horizon; type 8 has a pseudogley soil characterized by surface gleying resulting from perched water tables. Moreover, the same tree-physiological potential, cover and vegetation type may occur on two different soils (type 11), but is recognized as belonging to the same habitat type.

The soil names, alpha-, beta- and gamma-gley (habitat types $3,4,6$ and 11) refer to the position of true gleying or mottling in the $\mathrm{A}, \mathrm{B}$, or $\mathrm{C}$ horizons 


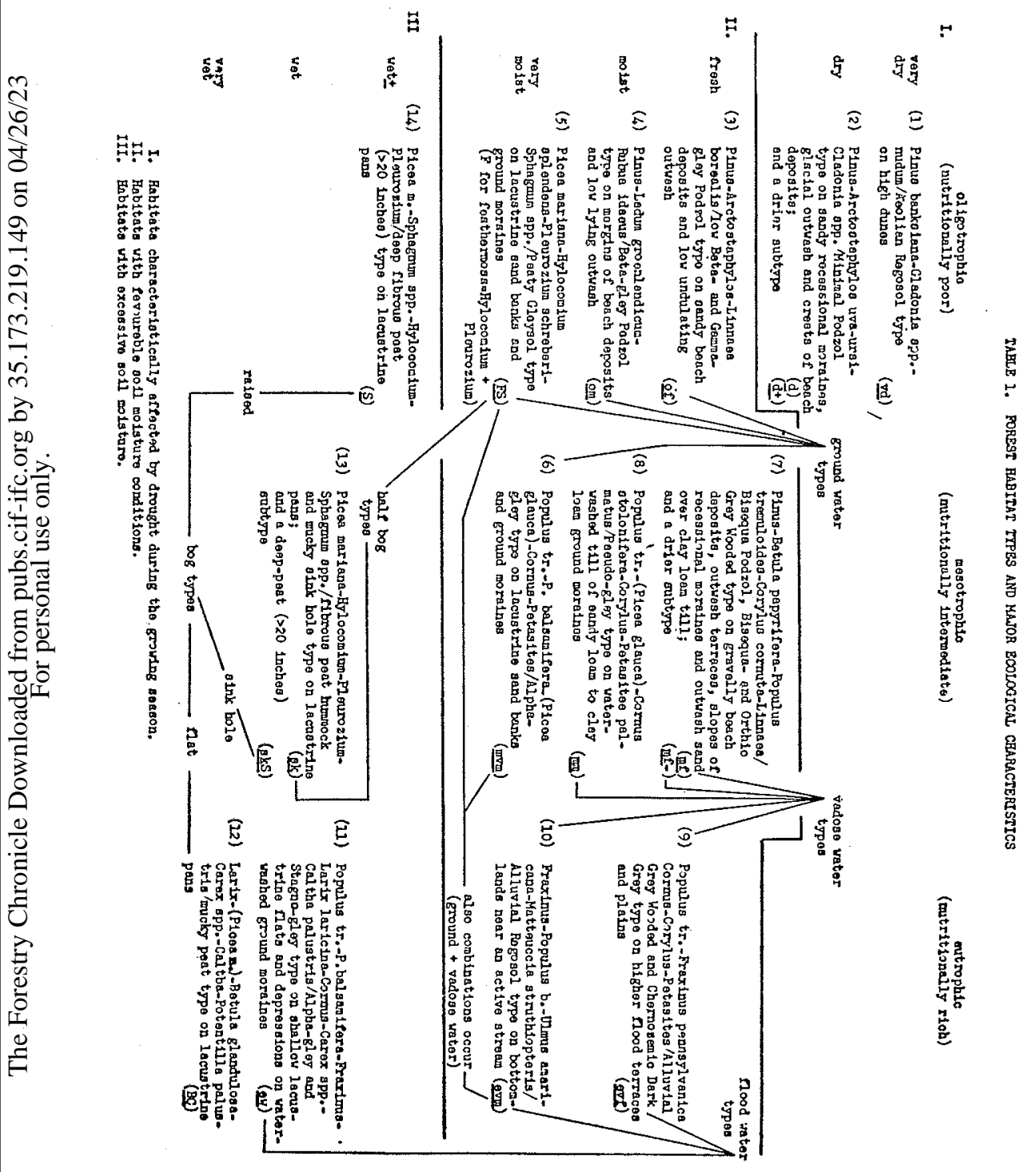

GTOINOYHO XУLSAYOH 
respectively (terminology from Wilde, 1957). The soil names pseudo- and stagno-gley (borrowed from International soil terminology) refer to surfacegley soils, the stagno-gley being an extreme pseudo-gley. The rest of the soil names are defined in the 1960 Report of the National Soil Survey Committee of Canada. The lesser vegetation types are those that are found under forest cover. Vegetation types of burned and logged areas are not shown.

In Table 1 the fourteen habitat types and three subtypes are organized and described by their major ecological characteristics. The subtypes (listed with types 2, 7 and 13) are outwardly similar to their main types, and are therefore not shown in Figure 1. They are treated as subtypes for purposes of field identification only. Type symbols are abbreviations of names based on major environmental features (e.g. $v d=$ very dry). Types 5, 12, 13 and 14 are organic terrain types, which is indicated by reference lines marking half bog and bog types. The rest are mineral terrain types.

Nutrient regime designations separate the types into three vertical columns. The term oligotrophic (nutritionally poor) is applied to habitats on colloidpoor, podzolized sands (types 1-4), and to habitats on organic terrain on which sphagnum and/or feathermoss peat form a closed carpet (closed fibrous-peattypes 5 and 14). The term mesotrophic (nutritionally intermediate) is applied to habitats on colloid-enriched, calcareous soils of sandy or finer texture (types 7 and 8 ) or to habitats that have a permanently high calcareous water table (type 6), and to habitats on organic terrain which are not entirely covered with sphagnum and/or feathermoss peat and which show flat, mucky depressions (sink holes) covered with eutrophic mosses and sedges (type 13). The term eutrophic (nutritionally rich) applies to alluvial habitats with deep Ah horizons (types 9, 10) or to wetland habitats with rich but shallow black muck layers (type 11) or to low moor bogs or "flat" bogs that have a deep, black mucky peat soil (type 12).

Horizontal lines separate the types into three broad soil moisture groups. Group II contains the most productive habitats in terms of total organic matter, productivity of which increases towards the right. This does not apply to productivity as expressed by site index (height/age relationship), as site index is also a reflection of competition for available water. Within the soil moisture groups habitats are separated by smaller moisture differences expressed as moisture regimes (sensu Hills, 1952).

The soil water designations-ground water, vadose water and flood waterrefer to the mechanisms by which the major soil water supply becomes available. Ground water systems occur in sandy soils of low water holding capacity in which a horizontally continuous water table is held up within the solum by an underlying impervious substratum. Vadose water systems occur in soils of higher water holding capacity. These may be either sandy soils with colloid-enriched Bt horizons or soils that have a finer texture throughout. If water tables occur in the solum of vadose water types they are only perched and not horizontally continuous. Flood water systems occur in alluvial habitats near streams or in low places (in any location) on which water is ponded in the spring. 


\section{Air-Photo Orientation Key}

This key is intended for "orientation" as a major step toward map completion in the field. It is divided into five sections with several alternative solutions in each. The procedure requires reading through all alternatives in one section before proceeding to the next. "Remarks" are found at ends of sections.

Habitat type numbers refer to Figure 1 and Table 1 . Symbols are explained in Table 1.

SECTION I

1. Black spruce, tamarack and cedar________organic soil terrain (Section II) (see Remark 1)

2. Jack pine, mixed wood and hardwood___mineral soil terrain (Section III)

3. Combinations of cover species of 1 . and 2 .

They occur on moist to wet mineral

soil terrain:

Jack pine-black spruce (not common) _om type (No. 4)

Tamarack-hardwood ___ ew type (No. 11)

Cedar-hardwood (extremely rare) ......mvmz type (No. 6)

Remark 1

A few stands of pure black spruce have been found on mineral terrain (om type 4 only). However, in southeastern Manitoba as a whole, they are extremely rare because of repeated fires.

SECTION II

Organic soil terrain:

1. Cedar (not common)

half bogs: FS (No. 5) and sk types, usually sk

2. Tamarack: (No. 13) (see Remark 3)

a. very short, stunted $<20$ feet tall interspersed with treeless areas, which show open water veins or scattered small, roundish lakes floating bog (not further differentiated)

b. normally stocked; trees at least 20-25 feet tall BC low moor type (No. 12)

c. very densely stocked. skS sink hole, deep peat, subtype (No. 13)

3. Black spruce-tamarack:

a. very short, stunted $<20$ feet tall interspersed with treeless areas, which show open water veins or scattered small, roundish lakes. Here black spruce forms typically small, conical islands floating bog (not further differentiated)

b. trees at least 20-25 feet tall:

(i) forming large uniform, homogeneous stands, not dissected by open water veins or bog streams_skS sink hole, deep peat, subtype (No 13)

(ii) stands dissected frequently by open water veins $B C$ low moor type (No. 12) 
4. Pure black spruce:

$$
\begin{aligned}
& \text { one of four possibilities: } F S \text {, sk half bog types (No. 5, 13) } \\
& \text { S, skS bog types (No. 14, 13) } \\
& \text { (See Remarks } 2 \text { and 3) }
\end{aligned}
$$

Remark 2

It is very difficult to separate half bog from bog types on air photographs, with the exception of the $B C$ low moor type. The following aids may be used:

Location. Half bogs ( $F S, s k$ types) are usually found adjacent to mineral soil terrain.

Tree height. If adjacent half bog and bog types are covered with black spruce stands that originated after the same fire, they can be separated on the basis of tree height, half bogs having the taller trees.

Remark 3

A definite separation of the sink hole types ( $s k$ and $s k S$ ) from the closed-fibrous-peat types ( $F S$ and $S$ ) is difficult without ground checking. The following aids may be used:

Location. Can be estimated from the flow pattern in bogs. On both sides of bog streams peaty meadows usually occur, beyond them is the $B C$ low moor type, then follow the sink hole types and finally the closedfibrous-peat types. If several bog streams occur over short distances, the closed-fibrous-peat types are usually absent.

Cover composition. Peaty meadows are treeless or covered only with clumps of willow and swamp birch. The $B C$ type is typically covered with tamarack, the sink hole types with mixed black spruce and tamarack, and the closed-fibrous-peat types with pure black spruce.

SECTION III

Mineral soil terrain:

1. Areas covered by pure jack pine or pinehardwood

oligotrophic upland and drier mesotrophic upland types (Section IV)

2. Areas covered by pure hardwood or hardwood mixed with conifers other than pine ....eutrophic flood water and mesotrophic upland types (Section V)

Section IV

Oligotrophic upland $(v d, d+, d$, of, om) and drier mesotrophic upland types (mf-, $m f)$. These can be recognized through landforms, position and vegetation characteristics:

Landform types ( 1 to 5 ):

1. Ridges and positions on undulating, upper terrain of extensive sand dune complexes, surrounded by other sandy textured upland terrain; stands composed of pure jack pine only, typically with scattered windfalls, trees with feeble crowns____.... $v d$ type (No. 1) (see Remark 4)

2. Ancient beaches; recognized by their narrow longitudinal shapes, commonly cutting through organic terrain. 
Position types (a to $\mathrm{c}$ ):

a. Crests on high (at least 10 feet relative to surrounding landform) and broad (at least $150 \mathrm{feet}$ ) beaches..._.... $d$ or $m f$ - type (No. 2 or 7) (see Remark s)

b. Gentle mid-slopes on high and broad beaches; or crests on low and narrow beaches; usually covered by thrifty pure jack pine stands

c. Lower slopes forming marginal bands along beach deposits; outer margin coincident with jack pine cover type boundary; typically some black spruce in understorey (not easily identifiable) _-_om type (No. 4)

3. Outwash deposits; recognized by their broad areal extent and frequently by steps that separate adjoining terraces; the latter may differ by from 2 to 20 feet in elevation.

Position types (a to $c$ ) :

a. High terraces, occurring in the midst of mineral soil terrain, that is, some distance away from organic terrain.... mf- or $d$ type (No. 7 or 2) (see Remark 5)

b. Intermediate terraces; singled out by eliminating the high and low terraces... $m f$ or of type (No. 7 or 3) (see Remark 5)

c. Low terraces, adjoining organic terrain or other kinds of "wetlands". -om type (No, 4)

4. Recessional moraines; recognized by undulating relief, differ from dunes by showing longer, gentler slopes and an irregularly winding ground arrangement.

Position types (a to $\mathrm{c}$ ) :

a. Gently undulating relief (ridges and depressions) $d$ type (No. 2)

b. Occasionally outstanding, higher ridges $d+$ subtype (No. 2)

c. Pronounced, dry-gully depressions (rare) and steep slopes at margins of recessional moraine complexes. $m f$ type (No. 7) (including $m f$ - subtype)

5. Waterwashed ground moraines; recognized as broad, smooth flats, similar to outwash deposits, but separated from these by absence of regular terraced steps; minor concave- and convex-shaped relief variations (of up to about 6 feet elevational difference) are a characteristic feature; in some areas exposed erratics may help to identify ground moraines.

Position types ( $a$ and $b$ ) :

a. High ground moraines; recognized by large areal extent, uniformity of tree cover, and absence of mosaicly interspersed, or immediately surrounding "wetlands"; if a 
high ground moraine adjoins organic terrain, it is semarated by abrupt, steep slopes.

Two kinds: coarse textured and fine textured.

Coarse textured, that is, sand; covered with homogeneous $d$ type (No. 2)

Fine textured, that is, loamy sand to sandy loam; covered with stands of pine (including red pine in places) and hardwood (white birch and/or aspen) that interchange mosaically, or covered with homogeneous hardwood-pine stands

b. Low ground moraines; recognized by mosaic pattern of interchanging mineral and organic soil terrain; here mostly half bogs or treeless "wetlands"; the latter indicate ground water near the surface within mineral soil terrain; presence of jack pine on these indicates sandy texture; (finer textured low ground moraines have no pine as stand component in southeastern Manitoba). The pitted mineral soil relief shows two types.

- in concave-shaped places and adjacent to "wetland" or organic terrain om type (No. 4)

- in convex-shaped places (usually of broad areal extent) ...of type (No. 3)

\section{Remark 4}

The typically short slopes down to surrounding terrain usually grade quickly from $d+$ to of types, but they are too small for mapping on 1:15,840 air photographs.

Renıark 5

The drier mesotrophic upland types, $m f$ - and $m f$, which occasionally occupy similar position as the $d$ and of types, respectively, can be separated from the latter oligotrophic types as follows:

\section{Cover composition}

Jack pine mixed with hardwood (white birch and/or aspen) $m f$ - and $m f$ types (No. 7)

Pure jack pine - with fairly dense arborescent shrub layers beneath tree canopy

—without shrub layers $d$ and of types (No. 2 and 3 )

Gravel pits, if present, also indicate the mesotrophic upland types.

SECTION V

Eutrophic flood water (evf, evm,ew) and mesotrophic upland types ( $m f-, m f, m m, m v m$ ); these are best recognized through areal extent and shape, location with respect to surrounding terrain, and cover composition:

1. Meandering bands of homogeneous hardwood stands, usually with high ash and/or elm component; recent alluvium, adjacent to active streams; bands of ten of irregular width about stream. Position types ( $a$ and $\mathbf{b}$ ):

a. Low terrace or alluvial bottomland; recognizable usually by higher elm component. 
b. High terrace or higher flood plain; separated from bottomland usually by discinct steps. ovf type (No. 9)

2. Patchy hardwood composed of aspen and/or white birch on positions of landform types usually occupied by jack pine or pine-hardwood $m f$ - and $m f$ types (No. 7 ) (Section IV)

3. Extensive hardwood with some balsam poplar and ash, rarely an isolated white spruce, on large, pitted flats: low, stony loam to clay-loam, waterwashed ground moraines.

Position types ( $a$ and $b$ ):

a. Patchy depressions, ponded in spring, road ditches usually water-filled in summer .ew type (No. 11)

b. Level ground, road ditches water-filled in spring, usually dry in summer mm type (No. 8)

4. Patchy hardwood often mixed with conifers other than pine, surrounded usually on one side by pine-occupied sandy textured landform types (beaches and low ground moraines) on the other by organic terrain and/or treeless "wetlands".

- flaring out margins of beach deposits or depressions on low lying, sandy textured ground moraines; of ten recognizable by spruce-hardwood stands.

- lacustrine sand banks or sand flats adjacent to beach deposits or merging into low lying, sandy textured ground moraines, commonly over-run with deltaic streamlets; of ten recognizable by tamarack-hardwood stands_._........ew type (No. 11)

\section{KEY For Freld MAPPING}

The key gives, at each step, two alternatives that lead to the next solution. Habitat type numbers refer to Figure 1 and Table 1 . Symbols are explained in Table 1 (Scientific names of species are listed following the key.)

1. a Habitats on organic terrain (overlying organic matter $>6$ inches deep)

1.b Habitats on mineral terrain (overlying organic matter $<6$ inches deep)

2. a Habitats on firm, consolidated peat that does not move with fluctuations of the water table

2. b Habitats on "swimming" peat that moves up and down with periodic changes of water table; tree cover, if present, stunted, not taller than about $15-20$ feet______floating bog (not differentiated)

3. a Habitats covered dominantly with tamarack, swamp birch and tall sedges; surface is relatively smooth, and may be covered with low hummocks which may occupy up to $50 \%$ of the area

3. b Habitats covered dominantly with black spruce (or black spruce stumps), occasionally with white cedar; surface with pronounced hummocks which occupy more than $50 \%$ of the area

4. a Habitats with shallow peat; up to 20 inches deep (measured from depressions between hummocks) $=$ half bog types.

4. b Habitats with peat deeper than 20 inches, almost never covered with white cedar

5. a Habitats with level, muck-filled depressions ( $=$ sink holes), which may range from about $1-6$ feet in diameter 
5. b Habitats without muck-filled depressions, instead depressions covered with sphagnum, typically with upland herbs (e.g. palmate-leaved coltsfoot, dewberry, bunchberry)

6. a Habitats with level, muck-filled depressions (= sink holes), which may range from about 1 - 6 feet in diameter

6. b Habitats without muck-filled depressions; instead depressions covered with sphagnum; sphagnum and feathermoss peat forms a continuous hummocky sheet, herbaceous vegetation sparse

7. a Habitats covered dominantly with pine (or pine stumps)

7. b Habitats covered dominantly with hardwoods, spruces or arborescent shrubs

8. a Habitats on ancient sand dunes on which green alder is absent from local depressions

8. b Habitats on other sandy-textured landform types, including dunes with green alder in local depressions.

9. a Habitats with bright, light grey mineral surface horizons (Ae $>1$ inch) on generally low lying coarse sandy deposits

9. b Habitats without bright, light grey mineral surface horizons ( $\mathrm{Ae}<1$ inch) when on sandy soils; on generally raised, level, undulating, or sloping positions; surface soil texture ranges from coarse sand to sandy loam

10. a Habitats with rusty mottling immediately below the bright, light grey mineral surface horizon; with only sporadic occurrence of bearberry or bearberry completely absent, with typically Labrador tea, green and sometimes speckled alder, and with moisture-indicating herbs (palmate-leaved coltsfoot, dewberry, bluebead-lily, bunchberry and horsetail species)

10. b Habitats without rusty mottling immediately below the bright, light grey mineral surface horizon; some patches of twinflower among bearberry, which here is usually prevalent, often with a few scattered bushes of green alder, and scattered bunchberry; Labrador tea, palmateleaved coltsfoot, bluebead lily and horsetail species usually absent; where recent ground fires have occurred common scouring-rush is usually abundant.

11. a. Habitats with dominantly low ericaceous shrubs (bearberry, teaberry, blueberry) giving the impression of a "clean" forest floor with only scattered larger shrubs present; bearberry forms typically a carpet, which may or may not be interrupted with barren needle-covered areas and/or large patches of reindeer lichens; the solum consists of uniform sand

11. b Habitats with dominantly non-ericaceous, medium-sized to arborescent shrubs (particularly snowberry and hazel) and abundant herbaceous vegetation (particularly grasses), pine cover often mixed with birch and/or aspen; the solum consists of either sands with $\mathrm{Bt}$ (colloid enriched) horizons or solums that consist entirely of loamy sand or sandy loam

12. a Habitats with abundant patches of reindeer lichen, and numerous barren, needle-covered spots (together occupying about $50 \%$ or more of forest floor), and very sparse herbaceous cover 
12. b Habitats with nearly complete surface coverage of bearberry and only few barren spots if any and with less abundant patches of reindeer lichen

13. a Habitats with fairly dense arborescent shrub layer, in which hazel is prominont; other characteristic shrubs are green alder, raspberry, snowberry, downy arrow-wood, bushhoneysuckle; many herb species; characteristically present is wild sarsaparilla; bearberry sporadic, twinflower always present

13. b Habitats with shrub layer usually less dense and snowberry typically dominant, hazel may be more sparsely represented; bearberry always present but usually patchy and interrupted by grasses and herbs; reindeer lichens typically absent or very sparse

14. a Habitats near active streams with typically ash and elm as stand component and with dark mineral surface horizons of "garden soil" characteristics

14. b Habitats in other locations

15. a Habitats on alluvial bottomlands whose surfaces are only about 2 to 4 feet above the stream-level in mid-summer; typically with dominant ostrich-fern among the undergrowth.........erm type (No. 10)

15. b Habitats on higher alluvial terraces, whose surfaces are more than 6 or 8 feet above stream-level in mid-summer and on which ostrich-fern is absent or only very sporadic.

16. a Habitats in which the upper mineral soil profile is of sandy texture

16. b Habitats on which the upper mineral soil profile is of loamy sand, loam or finer texture.

17. a Habitats in low, flat or depressional positions on flaring-out margins of beach deposits or on lacustrine sand with typically organic terrain in vicinity

bitats in raised positions on all sandy textured landforms except dunes

18. a Habitats with shallow black muck (up to 6 or 8 inches deep) overlying the mineral soil and with tall sedges and clumps of marsh-marigold

18. b Habitats with twin humus (typically root mor over mull) without tall sedges and marsh-marigold, of ten adjacent to and lower than om type.

19. a Habitats on low lying ground moraines with greyish and dark-greyish colored upper mineral soils, typically with faint yellowish mottling near the surface, and usually with deep (4 to 8 inches) blackish humus cover. bitats on raised ground moraines with yellowish and yellowish brown loamy sand textured surface soils and never with surface mottling, and with brownish to dusky red humus cover usually not exceeding 4 inches in depth.

20. a Habitats in local depressions with black muck humus cover and tall sedges and clumps of marsh-marigold evf type (No. 9) abitats on broad flats without tall sedges and marsh-marigold

The following 27 plant species are used in the key: bearberry (Arctostaphylos uva-ursi (L.) Spreng.), bluebead-lily (Clintonia borealis (Ait.) Raf.), blueberry (Vaccinium angustifolium Ait.), bunchberry (Cornus canadensis L.), bush-honeysuckle (Diervilla lonicerna Mill.), common scouring-rush (Equisetum hyemale L.), dewberry (Rubus pubescens Raf.), downy arrow-wood (Viburnum rafinesquianum Schultes), feathermoss (Hylocomium splendens 
Hedw.), green alder (Alnus crispa (Ait.) Pursh.), hazel (Corylus cornuta Marsh.), horsetail species (Equisetum pratense Ehrh. and E. sylvaticum L.) Labrador-tea (Ledum groenlandicum Oeder), marsh-marigold (Caltha palustris L.), ostrich-fern (Matteuccia struthiopteris (L.) Torado), palmate-leaved coltsfoot (Petasites palmatus Ait. Gray), raspberry (Rubus idaens L.), reindeer lichen (Cladonia spp.), Schreber's moss (Pleurozium schreberi (Bird) M.H.), snowberry (Symphoricarpos albus (L.) Blake and S. occidentalis Hook.), speckled alder (Alnus rugosa (Du Roi) Spreng.), swamp birch (Betula glandulosa Michx.), tall sedges (Carex aquatilis Wahlenb. and C. lacustris Willd.), teaberry (Gaultheria procumbens L.), twinflower (Linnaea borealis L.), wavy dicranum (Dicranum rugosum Brid.), wild sarsaparilla (Aralia nudicaulis L.).

\section{ConClusions}

Both keys have been tested by other foresters and are currently employed for silvicultural work in southeastern Manitoba, in particular for mapping habitats for cutting experiments, seed germination and survival studies. The keys could find similar application in mapping selected areas for reforestation on an operational scale. The speed of mapping, among other factors, depends largely on the complexity of the area, which varies from place to place. Mapping would require approximately one day per square mile in areas consisting mostly of ground water and half bog types, where 2 feet topographic variations can cause differences in habitats. Less time would be required for areas consisting largely of droughty and vadose water types, where such minor topographic variations are often insignificant. Bog types are commonly uniform over extensive areas and then can be mapped at correspondingly faster rates. The significance of the keys lies in providing an objective tool for habitat identification that can be used by foresters with only a cursory knowledge of the ecology of the region.

\section{ACKNOWLEDGEMENTS}

Acknowledgement is made to the Forest Research Branch, Canada Department of Forestry, under whose auspices the study was conducted. The author wishes to pay a special tribute to his late friend and inspiring colleague Jim S. Jameson, whose constructive criticism and active part in testing the validity of the keys helped to shape this paper.

\section{REFERENCES}

HILLS, G. A. 1952. The classification and evaluation of site for forestry. Ontario, Department of Lands and Forests, Division of Research, Res. Rep. 24.

JURDANT, M. 1964. Photo interpretation and forest land classification. Woodlands Review Section, Pulp and Paper Magazine of Canada, October 1964: 2-8.

MUELLER-DOMBOIS, D. 1964. The forest habitat types in southeastern Manitoba and their application to forest management. Canadian J. of Botany 42: 1417-1444.

NATIONAL SOIL SURVEY, CANADA, COMMITTEE OF-.1960. Report of the meeting at Guelph, Ont. 42 pp.

POWERS, W. E. 1952. A key to the photo-identification of glacial landforms and associated landform patterns. Dept. of Geography, Northwestern University, Evanston, Illinois, Tech. Report No. 2. 
ROWE, J. S. 1959. Forest Regions of Canada. Canada, Dept. Northern Affairs and National Resources, Forestry Branch, Bulletin 123.

SAYN-WITTGENSTEIN, L. 1961. Phenological aids to species identification on air photographs. Canada, Dept. Forestry, Forest Research Branch, Tech. Note No. 104.

WILDE, S. A. 1957. Forest soils. Ronald Press, New York. 537 pp.

ZSILINSKY, V. G. 1963. Photographic interpretation of tree species in Ontario. Ontario, Department of Lands and Forests Timber Branch. 